Annals of Warsaw University of Life Sciences - SGGW

Land Reclamation No 50 (3), 2018: 251-262

(Ann. Warsaw Univ. of Life Sci. - SGGW, Land Reclam. 50 (3), 2018)

\title{
Landscape valuation for planning ecotourism trails - case study
}

\author{
BEATA FORNAL-PIENIAK ${ }^{1}$, ANDRZEJ DŁUGOŃSKI ${ }^{2}$ \\ ${ }^{1}$ Faculty of Horticulture, Biotechnology and Landscape Architecture, Warsaw University of Life Sci- \\ ences - SGGW, Poland \\ ${ }^{2}$ Faculty of Biology and Environmental Sciences, Cardinal Stefan Wyszynski University, Poland
}

\begin{abstract}
Landscape valuation for planning ecotourism trails - case study. Ecotourism is a type of tourism strictly connected with natural and cultural landscape values. This kind of idea of "green travel" is perfect option for people who want to relax and sightseeing rural municipalities. It is really important to design eco-tourism trails, which are very usefulness for tourists in this area. The paper is presented natural and cultural values of Piaseczno municipality. It was done landscape valorization, which are included natural and cultural elements of this area. The purpose was to distinguished the areas with the high natural and cultural landscape values for eco-tourism trail design. It was used bonitation points to assessment in scale from 1 point to 5 points. The results were presented on maps, including areas with high, medium, low and very low landscape values. It was distinguished areas with minimum $50 \%$ of the maximum number of points were considered attractive for design eco-tourism trails.
\end{abstract}

Key words: ecotoursism trails, landscape valorization, Piaseczno municipality

\section{INTRODUCTION}

Ecotourism as a form of eco-friendly travel. "Green tourism" is also popular in Poland. It directly contributes to the protection of the natural and cultural environment of these regions, and its participants are people with high ecological awareness and sensitivity (Aldous 2013, Gibson 2014, Zaręba 2015). Ac- cording to the International Ecotourism Society, ecotourism is responsible travel to natural areas that preserves and protects the environment and improves the living conditions of local residents (McCombes et al. 2015). The beginnings of ecotourism date back to the 1970s (Jones and Spadafora 2017). Until recently, this form of travel was not known to a wider public. It is a starting point to find that environmentally-friendly travel can contribute to its protection. This thesis is also confirmed by the statements included in the Declaration on Ecotourism 2002 including, among others, the increase in interest in travel in natural areas, ecotourism is actively contributing to the protection of natural resources and the integrity of local communities, as well as to raising awareness all travelers on the preservation of natural and cultural heritage, ecotourism can have a positive economic dimension for the local population, its culture and future generations, and can be the main source of income for protected areas (Fancy 2002). Ecotourism is one of the fastest developing tourist markets in the world and is growing at a rate of $20-34 \%$ per annum (Jones and Spadafora 2017). This kind of idea of "green travel" and untouched nature is possible only due to 
the appropriate planning and controlling of the ecotourism product (Hawkes and Williams 1993, Zainoren et al. 2016). This management should include: control of tourist traffic in time and space, determination of zones serving different types of tourist penetration, tourism development adapted to the needs of the protected area. Because of unplanned and uncontrolled tourism largely destroys the environment, an eco-route scheme is proposed to protect the natural and cultural environment. The route directs the tourist traffic to the most natural and culturally sensitive areas of the municipality and at the same time protects the area against devastation while fulfilling ecotourism principles. From the above indications for planning eco-trails for landscape protection, it is clear that the activities of municipalities for ecotourism development and related environmental protection should not be limited only to the delineation of trails and management of their infrastructures (McCoy et al. 1995). A huge role in the success of ecotourism and at the same time protecting the landscape plays the development of the infrastructure of "green tourism" including eco-trails. That is why many municipal actions must focus on supporting in a variety of ways - financial, promotional - local communities (IUCN-WCPA 2000, Eshoo et al. 2018, Lee and Jan 2018).

The authors of the paper assumed the hypothesis that Piaseczno municipality has got high natural and cultural landscape values as potential for eco-tourism trails design. Therefore the aim of this work was to perform the landscape valorization of the Piaseczno municipality for eco-tourism trail design.

\section{MATERIAL AND METHODS}

\section{Characteristic of Piaseczno municipality}

Piaseczno municipality is located in the central part of the Mazowieckie Voivodeship, nearby Warsaw. The surface of municipality is 12,823 ha. Piaseczno municipality is one of the most forested areas in the Warsaw agglomeration.

\section{Methods}

Landscape valorization is a usefulness method for analysis of landscape values (Żarska 2001, Kil and Kowalczyk 2011, Łukowiak et al. 2017). There are many landscape valorization methods as: Janecki's straight lines method (Janecki 1981), Wojciechowski method (1986), Gacka-Grześkiewicz et al. method (1994), Żarska method (2001), Wolski method (1992). It is necessary to collected many information about natural and cultural elements before the landscape evaluation (Litwin et al. 2009). Landscapes are very diversified, so sometimes is needed to do modification of two, or three valorization methods. After that it is possible to achieved good results with valuable information about values of studded area (Litwin et al. 2009). Most of valorization methods are based on bonitation point consisting in assigning point values to individual elements. However, the most important criterions for choosing a particular method of landscape valorization is the aim of this assessment (Bajerowski 2007, Myga-Piątek 2007, Żarska 2011, Mazurski 2012, Ziembla 2012). After analyzing many valorization methods for tourism, a method developed by Kulczyk and Lewandowski 
TABLE 1. Types of spatial-landscape units

\begin{tabular}{|c|c|c|c|}
\hline $\begin{array}{c}\text { Unit } \\
\text { number }\end{array}$ & Type of spatial-landscape unit & \begin{tabular}{|c|} 
Unit \\
number
\end{tabular} & Name of special-landscape unit \\
\hline 1 & build up areas & 38 & build up areas \\
\hline 2 & $\begin{array}{l}\text { areas with cultivations, wasteland and } \\
\text { railway }\end{array}$ & 39 & areas with cultivations \\
\hline 3 & build up areas & 40 & areas with grasses vegetation \\
\hline 4 & $\begin{array}{l}\text { areas with grasses vegetation and } \\
\text { cultivations }\end{array}$ & 41 & areas with cultivations \\
\hline 5 & $\begin{array}{l}\text { areas with grasses vegetation and } \\
\text { cultivations }\end{array}$ & 42 & build up areas \\
\hline 6 & build up areas & 43 & forest areas \\
\hline 7 & forest areas & 44 & forest areas \\
\hline 8 & forest areas & 45 & forest areas \\
\hline 9 & forest areas & 46 & forest areas \\
\hline 10 & forest areas & 47 & areas with cultivations \\
\hline 11 & forest areas & 48 & forest areas \\
\hline 12 & forest areas & 49 & build up areas with cultivations \\
\hline 13 & build up areas & 50 & borest areas \\
\hline 14 & forest areas & 51 & areas with cultivations \\
\hline 15 & areas with grasses vegetation & 52 & forest areas \\
\hline 16 & build up areas with cultivations & 53 & build up areas with greenery \\
\hline 17 & forest areas & 54 & areas with cultivations \\
\hline 18 & forest areas & 55 & build up areas \\
\hline 19 & forest areas & 56 & build up areas \\
\hline 20 & build up areas with grasses vegetation & 57 & areas with surface waters and plantings \\
\hline 21 & forest areas & 58 & build up areas with cultivations \\
\hline 22 & forest areas & 59 & build up areas \\
\hline 23 & surface water & 60 & forest areas \\
\hline 24 & areas with grasses vegetation & 61 & forest areas \\
\hline 25 & build up areas & 62 & areas with cultivations \\
\hline 26 & $\begin{array}{l}\text { areas with cultivations and grasses } \\
\text { vegetation }\end{array}$ & 63 & areas with cultivations and forests \\
\hline 27 & $\begin{array}{l}\text { areas with grasses vegetation and } \\
\text { surface waters }\end{array}$ & 64 & build up areas with grasses vegetation \\
\hline 28 & build up areas & 65 & build up areas \\
\hline 29 & areas with cultivations & 66 & $\begin{array}{l}\text { areas with cultivations and grasses } \\
\text { vegetation }\end{array}$ \\
\hline 30 & areas with cultivations & 67 & greenery areas \\
\hline 31 & build up areas & 68 & surface waters \\
\hline 32 & forest areas & 69 & build up areas with cultivations \\
\hline 33 & build up areas & 70 & forest areas \\
\hline 34 & forest areas & 71 & build up areas with cultivations \\
\hline 35 & forest areas & 72 & build up areas with cultivations \\
\hline 36 & forest areas & 73 & forest areas \\
\hline 37 & forest areas & 74 & service areas \\
\hline
\end{tabular}


(2006) was used in Piaseczno municipality valorization. This method is focused more on the attractiveness of nature than on other parameters such as tourist infrastructure. The reason is that the natural environment has the high impact on the quality of ecotourism development. The authors of the chosen method proposed in their work bonitation points for assessment of eight elements as: land use, nature of the sculpture, geological structure, landscape, fauna, forms of nature protection, anthropogenic values and the presence and quality of view- points. For the needs of the Piaseczno municipality valorization the criteria of assessment were adjusted, giving up the element - geological structure because the area under development does not have a large diversity of geological forms such as rock forms. Criterias as landscape uniqueness and viewpoints were also abandoned, and the following criteria were introduced: vegetation with two sub-criterias - naturalness of plant communities, recreational usefulness of forest communities, surface water and ecotourism infrastructure occurring. Ac-

TABLE 2. Valorization of the Piaseczno municipality for ecotourism with assessment scale

\begin{tabular}{|c|c|c|c|c|c|}
\hline \multicolumn{2}{|c|}{$\begin{array}{l}\text { Main criteria } \\
\text { and subcriteria }\end{array}$} & \multirow{2}{*}{$\begin{array}{l}5 \\
- \\
-\end{array}$} & \multirow{2}{*}{$\begin{array}{c}3 \\
\text { big }\end{array}$} & \multirow{2}{*}{$\frac{2}{\text { medium }}$} & \multirow{2}{*}{$\begin{array}{c}1 \\
\text { small }\end{array}$} \\
\hline Land use & $\begin{array}{l}\text { mosaic of } \\
\text { land use }\end{array}$ & & & & \\
\hline \multirow[b]{2}{*}{$\begin{array}{l}\text { Vegeta- } \\
\text { tion }\end{array}$} & $\begin{array}{l}\text { naturalness } \\
\text { of vegetation }\end{array}$ & - & $\begin{array}{l}\text { forest - natural } \\
\text { and semi-natu- } \\
\text { ral }\end{array}$ & $\begin{array}{l}\text { non-forest - natu- } \\
\text { ral vegetation }\end{array}$ & - \\
\hline & $\begin{array}{l}\text { usefulness } \\
\text { of forest } \\
\text { vegetation } \\
\text { for recreation }\end{array}$ & - & $\begin{array}{l}\text { large recre- } \\
\text { ational value of } \\
\text { forest }\end{array}$ & $\begin{array}{l}\text { medium recre- } \\
\text { ational value of } \\
\text { forest }\end{array}$ & - \\
\hline \multicolumn{2}{|c|}{ Terrain sculpture } & - & - & typical forms & single forms \\
\hline \multicolumn{2}{|c|}{ Surface water } & $\begin{array}{c}\text { natural } \\
\text { or semi-natural } \\
\text { watercourse } \\
\text { or natural } \\
\text { reservoir }\end{array}$ & $\begin{array}{l}\text { water stream } \\
\text { regulated or } \\
\text { artificial water } \\
\text { reservoir }\end{array}$ & - & - \\
\hline \multicolumn{2}{|c|}{ Fauna } & - & fauna refuge & $\begin{array}{l}\text { large opportuni- } \\
\text { ties to meet and } \\
\text { fauna observation }\end{array}$ & $\begin{array}{c}\text { opportunities } \\
\text { to meet and fauna } \\
\text { observation }\end{array}$ \\
\hline \multicolumn{2}{|c|}{$\begin{array}{l}\text { Forms of nature } \\
\text { protection }\end{array}$} & - & $\begin{array}{l}\text { nature reserve, } \\
\text { Natura } 2000\end{array}$ & regional park & $\begin{array}{c}\text { areas of protected } \\
\text { landscape }\end{array}$ \\
\hline \multicolumn{2}{|c|}{ Cultural values } & - & $\begin{array}{l}\text { well preserved } \\
\text { high-value his- } \\
\text { torical objects } \\
\text { in the region }\end{array}$ & $\begin{array}{c}\text { historical objects } \\
\text { of great value } \\
\text { in municipality } \\
\text { scale }\end{array}$ & $\begin{array}{c}\text { single valuable } \\
\text { cultural elements }\end{array}$ \\
\hline \multicolumn{2}{|c|}{ Ecotourism infrastructure } & - & $\begin{array}{l}\text { accommoda- } \\
\text { tion and food } \\
\text { services }\end{array}$ & trails & - \\
\hline
\end{tabular}


cording to the authors, the adopted criteria will allow a more complete assessment of the Piaseczno municipality.

The first stage of valorization was the division of the study area into spatial-landscape units. It was used here two main criteria/factors: landform and land use. It was distinguished 74 spatial-landscape units (Table 1) based on land use of Piaseczno municipality.

It was used criteria of assessment as: naturalness of vegetation, usefulness of forest vegetation for recreation, surface water, terrain sculpture, land use, fauna, forms of nature protection, cultural values, ecotourism infrastructure. The evaluation criteria with the assessment scale from 1 point to 3 points are presented in Table 2. Occurrence of a natural or seminatural watercourse or natural reservoir achieved extra 5 points, because of their unique values on this area. Each study areas could have a maximum of 28 points.

\section{RESULTS}

\section{Natural landscape}

The variety of forest habitats are about $30 \%$ of the whole Piaseczno municipality area. The most forests are located in the south-eastern part of the municipality and belong to the Chojnowski Regional Park. Smaller forest areas are located in the southern and western part of the study area. Mixed moist forest and alder occupy areas along Jeziorka river. These are areas with naturally high retention capabilities, hardly accessible, however, fulfilling important ecological and water protection functions. They are not suitable for recreation, but they are interest- ing landscape objects. Small areas of forests are located between built-up and open areas, too. They are fragments of small, tree-lined patches suitable for recreation isolated from each other.

Non-forest communities are represented by natural and semi-natural vegetation in the study area. Wet meadows with alder parts are located in Jeziorka river valleys. Smaller wetland areas are typical for agricultural areas in the vicinity of Siedliska, Jastrzębie, Pilawa and Orzeszyn, Chojnów, Pęchery, Bogatka, Złotokłos, Wola Gołkowska, Antoninów. Synantropical plants are mostly connected with settelments, orchardes, gardens, roads and cultivated areas. The most diversified fauna occurs in the Chojnowski Regional Park. There are foxes, badgers, martens, weasels, cowards and small animals like raccoon dogs, hedgehogs, moles and shrews. About 100 bird species nest as sparrow hawk, buzzard, tawny owl, eagle owl and long-eared owl are in the Chojnowskie Forests. There are also mute swan, black and white stork, gray heron, crane and harriers on water and wetlands habitats. Numerous pheasants, wild ducks and 20 fish species are in the Jeziorka lake. Among the reptiles and amphibians, are occurring numerous viviparous lizard, lizard and several species of frogs. Protected areas are covered $40 \%$ of the Piaseczno municipality area. There are represented by 5 nature reserves, 1 landscape park, 1 protected landscape area, 72 natural monuments, 1 ecological site, 1 nature and landscape complex and Natura 2000 areas (according to Study of conditions of spatial development of Piaseczno municipality and gmin of 2014 and field researches - Fig. 1). 


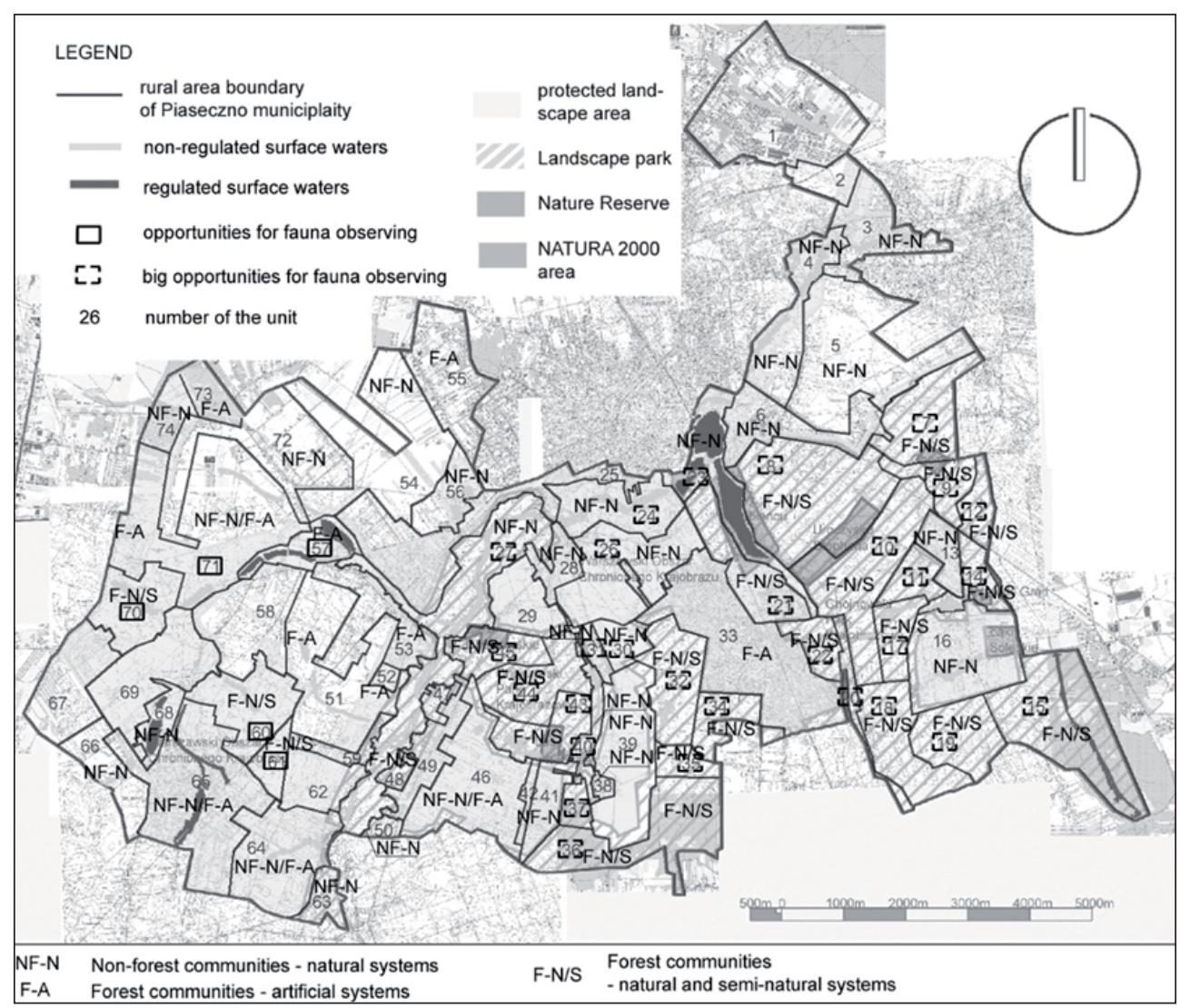

FIGURE 1. Natural landscape (own research)

\section{Cultural landscape}

There are memorial sites, archaeological sites, cemeteries and manor parks. It was located only five accommodation and catering facilities for ecotourism purposes in Piaseczno municipality. There are also hiking trails here, among others Chojnowski trail of natural monuments, the main trail of the Chojnowskie Forests, the South Route and the Magdalenka Trail-Zalesie Górne, bicycle routes and educational paths ${ }^{1}$. There are also equestrian centers and recreational shelters as well as another cultural objects (e.g. memorial places, historical churches, old buildings) showing the history of the site (Fig. 2).

1 http://www.krainajeziorki.pl/index.php/szlaki [accessed: 14.03.2018], http://piaseczno.eu/index. php?mu $=29$ [accessed: 16.03.2018]. 


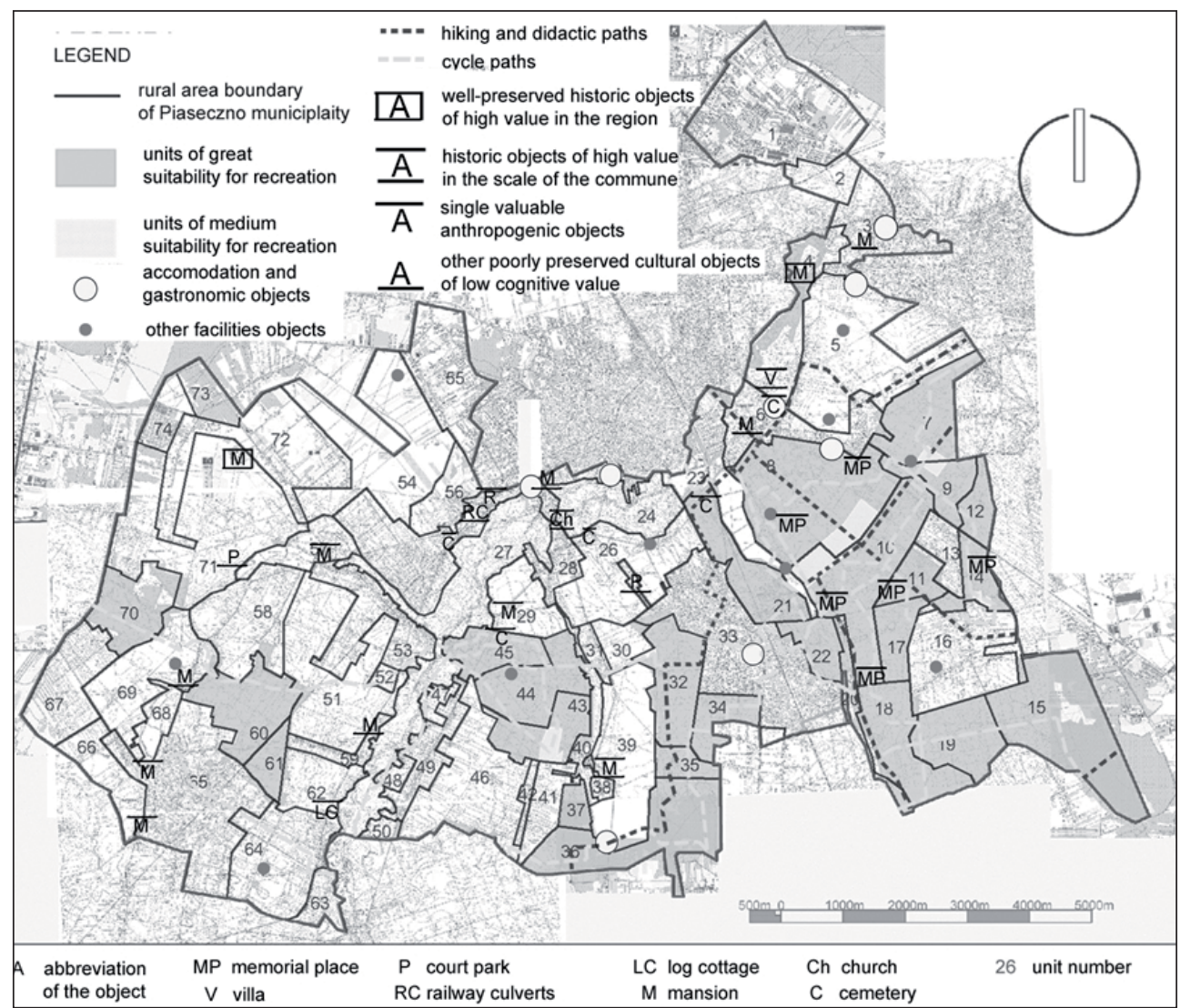

FIGURE 2. Cultural landscape (own study)

\section{Landscape valorization}

It was done valorization using nine criteria to assessment of Piaseczno municipality landscape. Piaseczno municipality landscape is very diversified. It was distinguished four types of areas (Table 3):

- areas with high landscape values (from 15 to 22 points) - 33 units;

- areas with medium landscape values (from 10 to 14 points) - 22 units;
- areas with low landscape values (from 5 to 9 points) - 13 units;

- areas with very low landscape values (from 0 point to 4 points) -5 units.

The spatial-landscape units with minimum $50 \%$ of the maximum number of points (min. 15 points), were considered attractive for ecotourism aspect. The results of the valorization and distribution of the spatial landscape units with high landscape values (from 15 to 22 points) are presented in Figure 3. 
TABLE 3. Landscape valorization results

\begin{tabular}{|c|c|c|c|c|c|c|c|c|c|c|}
\hline \multirow[b]{3}{*}{ 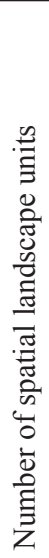 } & \multicolumn{8}{|c|}{ Landscape valorization } & \multirow[b]{3}{*}{ 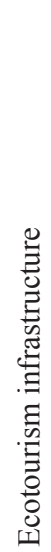 } & \multirow[b]{3}{*}{ 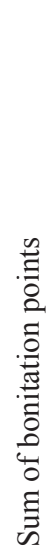 } \\
\hline & \multicolumn{2}{|c|}{ Vegetation } & \multirow[b]{2}{*}{ 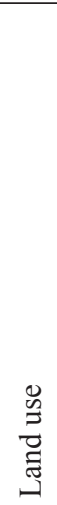 } & \multirow[b]{2}{*}{ 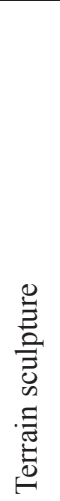 } & \multirow[b]{2}{*}{ 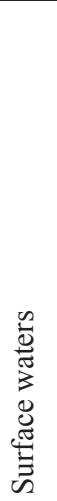 } & \multirow[b]{2}{*}{ 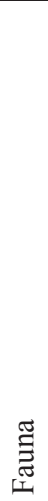 } & \multirow[b]{2}{*}{ 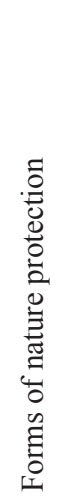 } & \multirow[b]{2}{*}{ 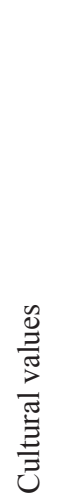 } & & \\
\hline & 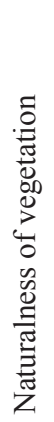 &  & & & & & & & & \\
\hline 1 & & & 2 & & 5 & & & & & 7 \\
\hline 2 & & & 2 & & & & 1 & & & 3 \\
\hline 3 & 2 & & 2 & & 5 & & 1 & & 3 & 13 \\
\hline 4 & 3 & 3 & 2 & & 5 & & 1 & 3 & & 17 \\
\hline 5 & 2 & & 2 & & & & 1 & & 2 & 7 \\
\hline 6 & 2 & & 2 & & 5 & & 1 & 1 & 3 & 14 \\
\hline 7 & 3 & 3 & & & & 3 & 3 & & 2 & 14 \\
\hline 8 & 3 & 3 & & 3 & 3 & 3 & 3 & 1 & 3 & 22 \\
\hline 9 & 3 & 3 & & & & 3 & 3 & & 2 & 14 \\
\hline 10 & 3 & 3 & & 3 & & 3 & 3 & 1 & 2 & 18 \\
\hline 11 & 3 & 3 & & 3 & 5 & 2 & 2 & 1 & 2 & 21 \\
\hline 12 & 3 & 3 & & & & 2 & 2 & & 2 & 12 \\
\hline 13 & 2 & & & & & & 1 & & & 3 \\
\hline 14 & 3 & 3 & & & 5 & 2 & 3 & 1 & 2 & 19 \\
\hline 15 & 3 & 3 & & & 3 & 2 & 2 & & 2 & 15 \\
\hline 16 & 2 & & 2 & & 5 & 3 & 3 & & 2 & 17 \\
\hline 17 & 3 & 3 & & & 5 & 2 & 2 & & 2 & 17 \\
\hline 18 & 3 & 3 & & 2 & & 2 & 2 & & 2 & 14 \\
\hline 19 & 3 & 3 & & & & 2 & 2 & & 2 & 12 \\
\hline 20 & 3 & 3 & 2 & 2 & 5 & 2 & 2 & & 2 & 21 \\
\hline 21 & 3 & 3 & 2 & 3 & & 3 & 3 & & 2 & 19 \\
\hline 22 & 3 & 3 & & 2 & & 2 & 2 & & 2 & 14 \\
\hline 23 & 3 & 3 & 1 & & 5 & 3 & 3 & 1 & 2 & 21 \\
\hline 24 & 2 & & 2 & 2 & 5 & 2 & 1 & 2 & & 16 \\
\hline 25 & 2 & & 2 & 2 & 5 & & 2 & 3 & 3 & 19 \\
\hline 26 & 2 & & 2 & 2 & 5 & 2 & 1 & 1 & 2 & 17 \\
\hline 27 & 2 & & 2 & 2 & 5 & 2 & 2 & 3 & 2 & 20 \\
\hline 28 & 2 & & 2 & 2 & 5 & & 1 & & & 12 \\
\hline 29 & 2 & & 2 & & & 2 & 2 & 1 & & 9 \\
\hline 30 & 2 & & & & & 2 & 2 & & 2 & 8 \\
\hline
\end{tabular}


TABLE 3, cont.

\begin{tabular}{|c|c|c|c|c|c|c|c|c|c|c|}
\hline 31 & 2 & & 1 & & 5 & 2 & 2 & & 2 & 14 \\
\hline 32 & 3 & 3 & & & 5 & 2 & 2 & & & 15 \\
\hline 33 & & & 1 & & 5 & & 2 & & 3 & 11 \\
\hline 34 & 3 & 3 & & & 5 & 2 & 2 & & 2 & 17 \\
\hline 35 & 3 & 3 & & & & 2 & 2 & & 2 & 12 \\
\hline 36 & 3 & 3 & & & 5 & 2 & 2 & & 2 & 17 \\
\hline 37 & & 3 & 1 & & 5 & 2 & 2 & & & 16 \\
\hline 38 & 2 & & 1 & & 5 & & 1 & 2 & & 11 \\
\hline 39 & 3 & & & & & & 2 & & & 5 \\
\hline 40 & 2 & 3 & 1 & 2 & 5 & 2 & 2 & & & 17 \\
\hline 41 & 2 & & & & & & 2 & & 2 & 6 \\
\hline 42 & 2 & 3 & 1 & & & & 2 & & 2 & 10 \\
\hline 43 & 3 & 3 & & & 5 & 2 & 3 & & 2 & 18 \\
\hline 44 & 3 & 3 & & & 5 & 2 & 2 & & 2 & 17 \\
\hline 45 & 3 & 3 & & 2 & 5 & 2 & 3 & 1 & 2 & 21 \\
\hline 46 & & & 2 & & 5 & & 1 & & & 8 \\
\hline 47 & 2 & & & 2 & 5 & 2 & 2 & & 2 & 15 \\
\hline 48 & & & & 2 & 5 & & 2 & & 2 & 11 \\
\hline 49 & 2 & & 1 & & & & 2 & & 2 & 7 \\
\hline 50 & 2 & 3 & & & 5 & & 2 & & & 12 \\
\hline 51 & 2 & & 2 & & 5 & & 1 & 3 & 2 & 15 \\
\hline 52 & & & & & & & 1 & & 2 & 3 \\
\hline 53 & 2 & 3 & 2 & 2 & 5 & 2 & 1 & 3 & 2 & 22 \\
\hline 54 & 2 & & 1 & & 5 & 1 & 1 & & 2 & 12 \\
\hline 55 & & & 2 & & & & & & & 2 \\
\hline 56 & 2 & 3 & 2 & & & & 1 & & & 8 \\
\hline 57 & 2 & 3 & 2 & 2 & 5 & 1 & 1 & 1 & & 17 \\
\hline 58 & 3 & & 2 & 2 & 5 & 1 & 1 & & & 14 \\
\hline 59 & 2 & & 2 & 2 & 5 & 2 & 2 & & & 15 \\
\hline 60 & 3 & 3 & & 2 & 5 & 1 & 1 & 3 & 2 & 20 \\
\hline 61 & 3 & 3 & & & & 1 & 1 & 3 & & 11 \\
\hline 62 & 2 & & 1 & & & 2 & 2 & & & 7 \\
\hline 63 & 2 & & 2 & 2 & & & 2 & & 2 & 10 \\
\hline 64 & 2 & & 2 & & 5 & & 2 & 1 & 2 & 14 \\
\hline 65 & 2 & 3 & 2 & & 3 & 1 & 1 & 3 & 2 & 17 \\
\hline 66 & 2 & & 1 & & 5 & & 0 & & & 8 \\
\hline 67 & & & 1 & & & & 1 & & & 2 \\
\hline 68 & 2 & & 2 & & 5 & & 1 & & 2 & 12 \\
\hline 69 & 2 & & 2 & 2 & 5 & 1 & 1 & & 2 & 15 \\
\hline 70 & 3 & 3 & 2 & 2 & 5 & 1 & 1 & & 2 & 19 \\
\hline 71 & 2 & 3 & 2 & 2 & 5 & 1 & 1 & 3 & & 19 \\
\hline 72 & 2 & & 2 & & & 1 & 1 & & & 6 \\
\hline 73 & & & 2 & & & & 1 & & & 3 \\
\hline 74 & 2 & & 2 & & & & 1 & & & 5 \\
\hline
\end{tabular}




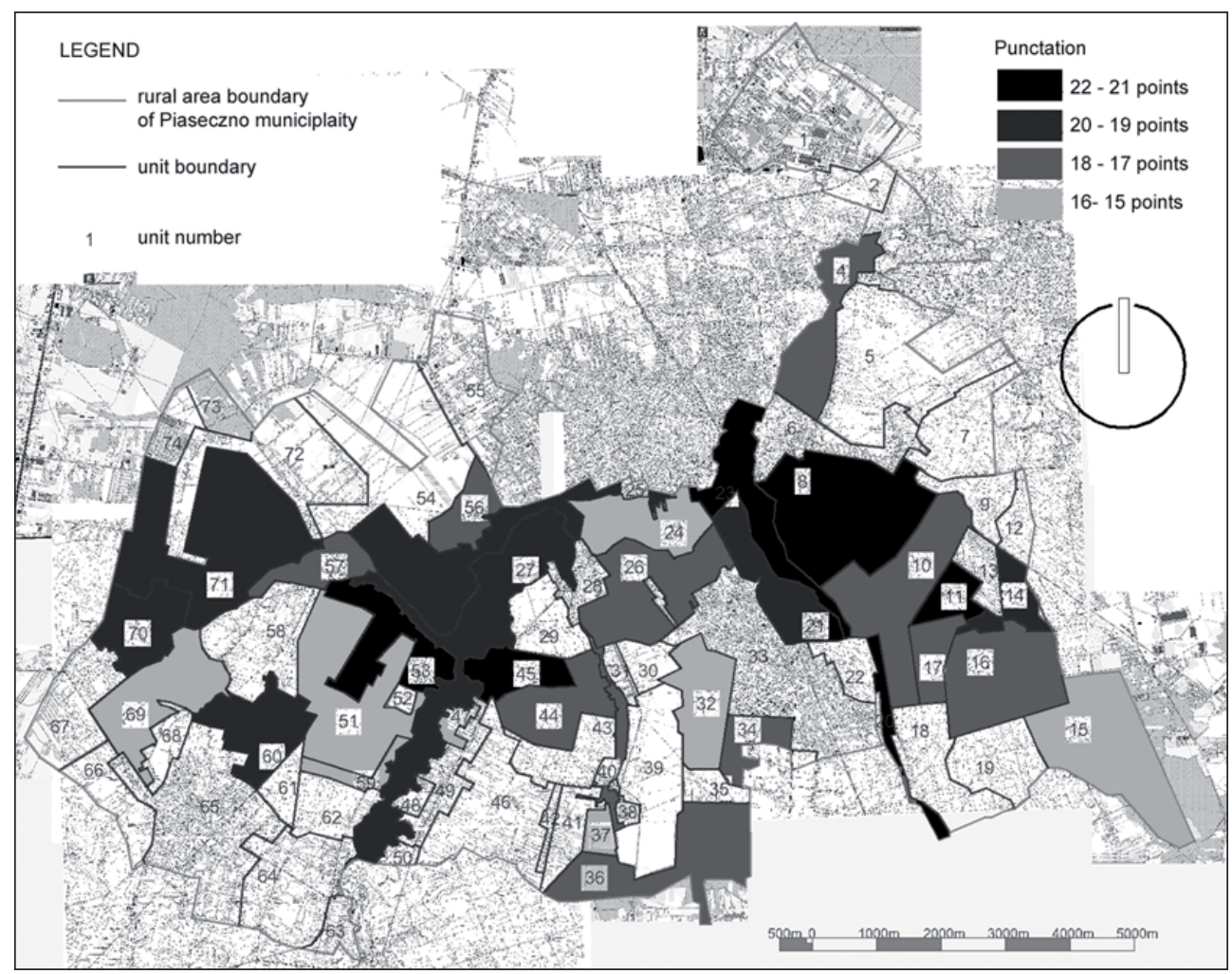

FIGURE 3. Spatial-landscape units with high landscape values for ecotourism aspect (own elaboration based on Kulczyk and Lewandowski (2006) method (own research)

\section{CONCLUSIONS}

The presented valorization method was used for indicates the areas of natural and cultural values of the Piaseczno municipality for the purpose of designing the ecotourism path. The application of this method may be the basis for determining the valuable natural resources of the others municipalities, e.g. agglomerations of big cities like Łódź, Poznań, Kraków. Application of this valorization method may be helpful in defining future directions of development ecosystem services of urban-rural municipalities, as well as being a determinant of a new trend in spatial landscape planning.

\section{REFERENCES}

ALDOUS D.E. 2013: Green Tourism on Sustainable Development. Int. Soc. Hortic. Sci. 999: 171-178.

BAJEROWSKI T., BIŁOZOR A., CIEŚLAK I., SENETRA A., SZCZEPAŃSKA A. 2007: Ocena i wycena krajobrazu. Educaterra, Olsztyn.

ESHOO P.F., JOHNSON A., DUANGDALA S., HANSEL T. 2018: Design, monitoring and evaluation of a direct payments approach for an ecotourism strategy to reduce illegal hunting and trade of wildlife in Lao PDR. PLoS ONE 13 (2). DOI 10.1371/journai.pone. 0186133

FANCY S. 2002: Monitoring natural resources in our national parks. National 
Park Service. Retrieved from: www.nature.nps.gov/im/monitor/textindex.htm.

GACKA-GRZEŚKIEWICZ E., WILAND M., CICHOCKI Z., CIEŚLAK M., ŻARSKA B. 1994: Ocena przyrody i krajobrazu w planowaniu przestrzennym gmin. Wydawnictwo Instytutu Ochrony Srodowiska, Warszawa.

GIBSON D. 2014: Green tourism alleviating poverty community-based ecotourism in Fiji. In: M. Jiang, T. Delacy, G. Lipman, S. Vorster, R. Hawkins (Eds.). Green growth and travelism - The academic viewpoint. Routledge, London: 159-173.

HAWKES S., WILLIAMS P. (Eds.). 1993: The Greening of Tourism From Principles to Practice: A Casebook of Best Environmental Practice in Tourism. Centre for Tourism Policy Research, Simon Fraser University Barnaby, BC.

IUCN-WCPA 2000: Protected Areas: Benefits beyond Boundaries - WCPA in Action. International Union for Conservation of Nature, Gland.

JANECKI J. 1978: Linia prosta w ocenie wartości krajobrazu. Problemy 10.

JONES G., SPADAFORA A. 2017: Ecotourism in Costa Rica, 1970-2000. Enterprise and Society 18 (1): 146-183. DOI 10.1017/eso.2016.50

KIL J., KOWALCZYK C. 2011: Landscape Valorization Methods and Sustainable Development. Contemporary Problems of Management and Environmental Protection Issues of Landscape Conservation and Water Management in Rural Areas 7: 17-25.

KULCZYK S., LEWANDOWSKI W. 2006: Ocena przydatności krajobrazu dla ekoturystyki na przykładzie okolic Chrobrza. Prob. Ekol. Kraj. 40: 191-199.

LEE T.H., JAN F.H. 2018: Development and validation of the ecotourism behavior scale. Int. J. Tour. Res. 20 (2): 191-203. DOI 10.1002/jtr.2172

LITWIN U., BACIOR S., PIECH J. 2009: Metody waloryzacji i oceny krajobrazu. Geod. Kartogr. Fotogr. 71: 14-25.
ŁUKOWIAK M., SZOPIŃSKA E., KURIATA Z. 2017: Managing suburban area using landscape. Evaluation and Valorization Methods. Econ. Environ. Stud. 17 (4): 923-934.

McCOMBES L., VanCLAY F., EVERS Y. 2015: Putting social impact assessment to the test as a method for implementing responsible tourism practice. Environ. Impact Assess. Rev. 55: 156-168.

McCOY K.L., KRUMPE E.E., ALLEN S. 1995: Limits of acceptable change: evaluating implementation by the U.S. Forest Service. IJW 1 (2): 18-22.

MAZURSKI K. 2012: Pojęcie krajobrazu i jego ocena. Proksena, Kraków.

MYGA-PIĄTEK U. 2007: Kryteria i metody oceny krajobrazu kulturowego w procesie planowania przestrzennego na tle obowiązujących procedur prawnych. In: M. Kistowski et al. (Eds.). Waloryzacja środowiska przyrodniczego w planowaniu przestrzennym. Polska Asocjacja Ekologii Krajobrazu, Gdańsk - Warszawa: 101-110.

RICHLING A. 1992: Podstawy metodyczne oceny wizualnej atrakcyjności krajobrazu. In: Metody oceny środowiska przyrodniczego. Gea 2: 9-18.

Urząd Miasta i Gminy Piaseczno 2014: Studium uwarunkowań i zagospodarowania przestrzennego miasta i gminy Piaseczno [Study of conditions of spatial development of Piaseczno municipality and gmina]. Skala 1:10 000. Uchwała nr 1589 LII 2014 z dnia 29 października 2014 r. W sprawie zmiany Studium Uwarunkowań i Kierunków Zagospodarowania Przestrzennego Miasta i Gminy Piaseczno. Piaseczno.

UNEP-WTO 2002. Declaration on Ecotourism 2002. Québec.

WOJCIECHOWSKI K.H. 1986: Problemy percepcji i oceny estetycznej krajobrazu. Wydawnictwo UMCS, Lublin.

WOLSKI P. 1992: O znaczeniu percepcji krajobrazu. In: Metody oceny środowiska przyrodniczego. Gea 2. Wydawnic- 
two WGiSR UW, Warszawa - Płock - Murzynowo: 5-10.

ZAINOREN A., ABDURAHMAN A., ALI J., K., YUSRINA L., KHEDIF B., BOHARI Z., ADLIN J., SILVERINA A., KIBAT A. 2016: Ecotourism Product Attributes and Tourist Attractions: UiTM Undergraduate Studies. Proc. Social. Behav. Sci. 15 (224): 360-367. DOI 10.1016/j.sbspro.2016.05.388

ZARĘBA D. 2015: Rozwój ekoturystyki w Polsce - przykłady dobrych praktyk [Ecotourism development in Poland - best practices]. In: T. Włoszczowski (Ed.). Ekoturystyka wobec globalnych wyzwań. Idee, trendy, dobre praktyki. Wydawnictwo Społecznego Instytutu Ekologicznego, Warszawa: 12-22.

ZIEMBLA K. 2012: Metoda JARK-WAK W ocenie krajobrazu kulturowego na przykładzie krajobrazu wsi Cyganek. Sztuka Ogrodu. Sztuka Krajobrazu 3: 17-26.

ŻARSKA B. 2001: Study of landscape protection - methodic of working out for various areas. Ann. Warsaw Agricult. Univ. - SGGW, Horticult. Landsc. Architect. 22: 111-122.

Streszczenie: Ocena krajobrazu w celu zaprojektowania szlaków ekoturystycznych - studium przypadku. Ekoturystyka jest rodzajem turystyki ściśle związanej z walorami przyrodniczymi i kulturowymi danego regionu. Ten rodzaj turystyki jest idealną opcją dla osób, które chcą się zrelaksować i zwiedzić obszary pozamiejskie o wysokich walorach krajobrazowych. Bardzo ważne jest projektowanie szlaków ekoturystycznych, które są przydatne dla celów rozwoju ekoturystyki. W artykule przedstawiono wartości przyrodnicze i kulturowe gminy Piaseczno oraz wykonano waloryzację krajobrazu w celu zwartościowania elementów środowiska naturalnego i kulturowego tego regionu. Teren opracowania podzielono na jednostki krajobrazowo-przestrzenne, a następnie sformułowano kryteria ich oceny. W ocenie zastosowano bonitację punktową w skali od 1 punktu do 5 punktów. Na podstawie otrzymanej waloryzacji wyróżniono obszary w czterech kategoriach: jednostki (obszary) o wysokich, średnich, niskich i bardzo niskich walorach krajobrazowych. Wyniki te umożliwiły wyznaczenie cennych obszarów gminy Piaseczno dla potrzeb zaprojektowania ścieżek ekoturystycznych. Badania dotyczące oceny krajobrazu są bardzo ważne dla planowania przestrzennego gmin w kontekście rozwoju m.in. ekoturystyki.

Stowa kluczowe: szlaki ekoturystyczne, waloryzacja krajobrazu, gmina Piaseczno

$M S$ received 04.04.2018

MS accepted 16.07.2018

\section{Authors' address:}

Beata Fornal-Pieniak

Katedra Ochrony Środowiska

Wydział Ogrodnictwa, Biotechnologii

i Architektury Krajobrazu

Szkoła Główna Gospodarstwa Wiejskiego

w Warszawie

ul. Nowoursynowska 159, 02-787 Warszawa

Poland

e-mail: beata_fornal_pieniak@sggw.pl 